\title{
Composition, Structure and Functional Feeding of Aquatic Entomofauna in Kodjoboué Lake: Water Quality Assessment
}

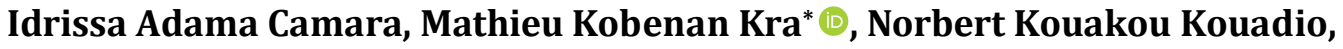 \\ Mexmin Koffi Konan, Edia Oi Edia, Lassina Doumbia, Allassane Ouattara, Dramane Diomande
}

Laboratoire d'Environnement et de Biologie Aquatique (LEBA), UFR-Sciences et Gestion de l'Environnement (SGE), Université Nangui Abrogoua (UNA), Abidjan, Côte d'Ivoire

Email: *mathieukra@gmail.com

How to cite this paper: Camara, I.A., Kra, M.K., Kouadio, N.K., Konan, M.K., Edia, E.O., Doumbia, L., Ouattara, A. and Diomande, D. (2020) Composition, Structure and Functional Feeding of Aquatic Entomofauna in Kodjoboué Lake: Water Quality Assessment. Open Journal of Ecology, 10, 160-176.

https://doi.org/10.4236/oje.2020.104011

Received: December 16, 2019

Accepted: April 4, 2020

Published: April 7, 2020

Copyright $\odot 2020$ by author(s) and Scientific Research Publishing Inc. This work is licensed under the Creative Commons Attribution International License (CC BY 4.0).

http://creativecommons.org/licenses/by/4.0/

\begin{abstract}
The composition, structure and Functional Feeding Groups (FFGs) of aquatic insects were investigated in Kodjoboué lake (South-East of Côte d'Ivoire) to assess water quality. Four sites (K1 - K4) were sampled during eight campaigns. At each site aquatic insects were collected using a kick-net $(25 \times 20$ $\mathrm{cm}, 500 \mu \mathrm{m}$ mesh size). Environmental variables were also recorded during this period. Water was collected from each sampling site for nutrient (phosphorus, nitrate) analysis in laboratory. A total of 68 aquatic insect taxa belonging to six orders and 32 families were recorded during the study. Site K4, subject to intense agricultural activity, had the lower diversity and least balanced stand with the lowest values of Shannon-Weaver index, Pielou's Evenness index and rarefied richness. The functional approach revealed five major FFGs: predators, scrapers, shredders, gatherers-collectors and filter-collectors. Among the different functional feeding groups, the percentage of predators was higher than that of other groups at all the sites. The P/R report indicated that our four sites are characterized as heterotrophic with K1 as the least heterotrophic. Focused Principal Component Analysis (FPCA) showed that parameters of water, like $\mathrm{pH}$, dissolved oxygen, nitrate were statistically correlated with species abundance. The diversity and Functional Feeding Groups metrics of aquatic insects used to describe the state of Kodjoboué lake reveal its disturbed state.
\end{abstract}

\section{Keywords}

Kodjoboué Lake, Aquatic Insects, Functional Feeding Groups, Taxonomic Diversity 


\section{Introduction}

Aquatic macroinvertebrates are the main group of organisms using to assess the ecological state of continental hydrosystems. They are recognized as the best indicators of the ecological health of hydrosystems through the use of the structure of their communities as an indicator of the effects of human activity on hydrosystems [1] [2] [3] but also, by having within them, bio-indicator species of water quality. Of the biological quality elements that have been used for water quality assessment, aquatic insects are most often recommended [4] due to their varying sensitivity to several abiotic and biotic factors in the environment [5]. They constitute the most diverse taxonomic group and the most abundant in aquatic environments [6]. The use of these organisms in bioindication is commonly done with taxonomic descriptors (diversity indices, taxonomic richness, relative abundances, indicator species) [7] [8] [9]. However, the functional approach is more appropriate and faster than the taxonomic approach to characterize ecosystem conditions [10]. As a result, the functional approach is increasingly used in the assessment of surface water quality [11] [12] [13]. Also, functional feeding groups measures do not require standardized sampling and different sampling methods can be used to assign aquatic invertebrates to functional feeding groups [14].

Despite the growing interest in the study of functional diversity, no attempt to our knowledge has been made to establish a diagnosis of water quality in Côte d'Ivoire.

In addition, while much work has been done on the macrofauna of some lakes in Côte d'Ivoire [15] [16] [17] [18] [19], very little data exists on Kodjoboué lake [20]. Given the importance of the functional feeding groups approach in biomonitoring and conservation, the evaluation of the functional organization of macroinvertebrate communities is essential [21], particularly that of aquatic insects. The aim of this study is to use the taxonomic composition and the functional feeding groups of the aquatic insects to assess the ecological state of Kodjoboué lake (South-East, Côte d'Ivoire).

\section{Materials and Methods}

\subsection{Study Area and Sampling Sites}

Kodjoboué lake is located in south-eastern Côte d'Ivoire in the South-Comoé region about $4 \mathrm{~km}$ south of the town of Bonoua between longitudes $3^{\circ} 35^{\prime} 9^{\prime \prime} \mathrm{W}$ and latitudes $5^{\circ} 14^{\prime} 11^{\prime \prime} \mathrm{N}$. This area is contiguous to the Grand-Bassam wetland and covers an area of $3.404 \mathrm{Km}^{2}$ [20]. This lake communicates with the Comoé river by a thin stream of water. This region has an average altitude of $90 \mathrm{~m}$, its climate is subequatorial with an average annual temperature ranged between $25^{\circ} \mathrm{C}$ to $33^{\circ} \mathrm{C}$. The rainfall varies from 1400 to $2500 \mathrm{~mm}$ /year and an annual rate of humidity about $80 \%$ to $90 \%$ [22]. This climate is characterized by four seasons: two dry seasons (mid-July to mid-September and December to March) and two rainy seasons (April to mid-July and mid-September to mid-November) [23]. Four 
sampling sites were selected in Kodjoboué lake (K1 to K4) (Figure 1). These sites were sampled during eight sampling campaigns from June 2014 to May 2017. Table 1 summarizes the characteristics of these sampling sites.

\subsection{Data Collection}

Aquatic insects of the native vegetation, covering the banks of the lake were

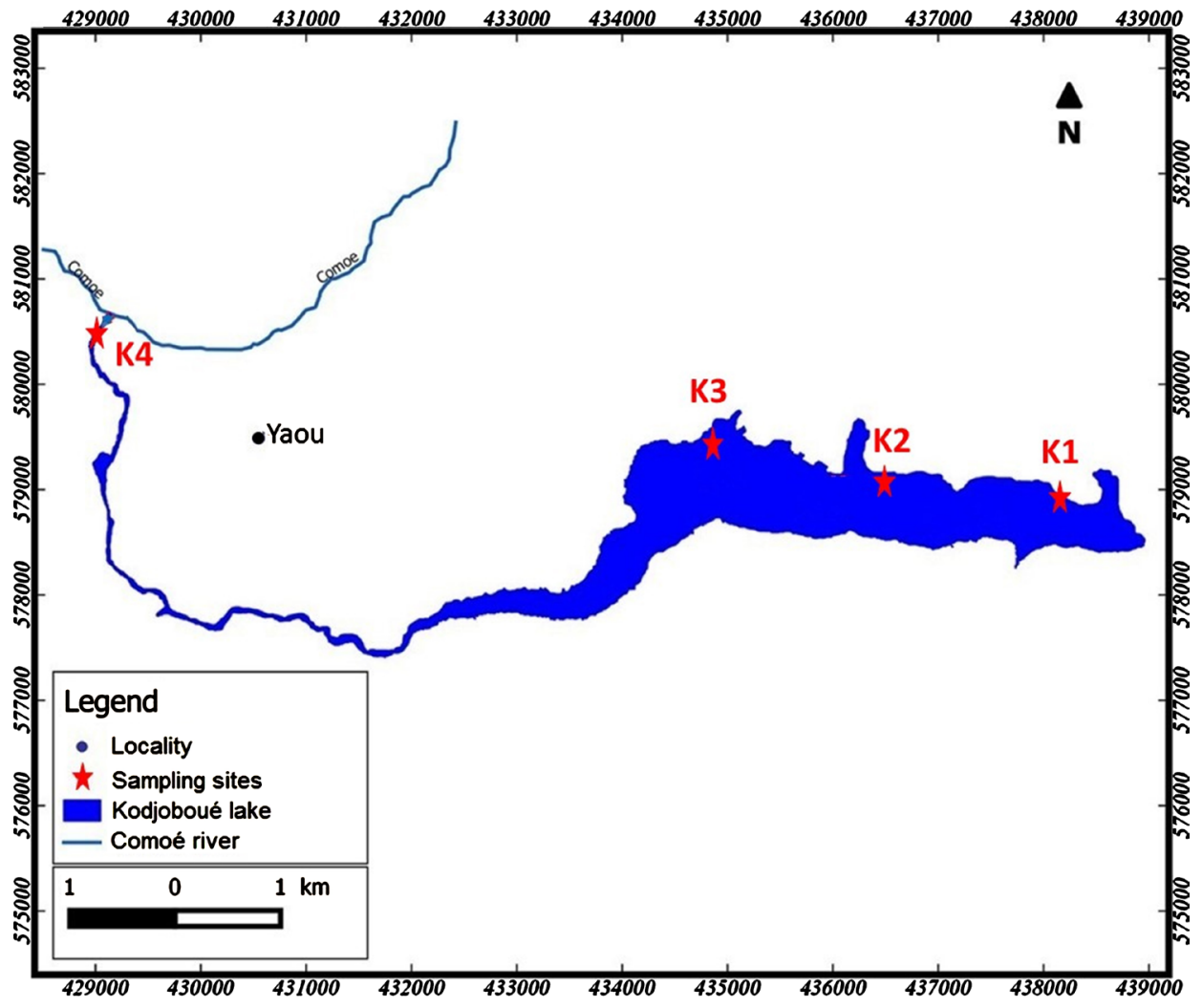

Figure 1. Location of the study area showing the four sampling sites of Kodjoboue lake (South-East, Côte d'Ivoire).

Table 1. Characteristics of the four sampling sites in Kodjoboué lake (South-East, Côte d'Ivoire).

\begin{tabular}{|c|c|c|c|c|c|c|}
\hline \multirow[t]{2}{*}{$\begin{array}{l}\text { Samplin } \\
\text { g sites }\end{array}$} & \multicolumn{2}{|c|}{$\begin{array}{c}\text { Geographical } \\
\text { positions } \\
\text { (UTM) }\end{array}$} & \multirow[t]{2}{*}{ Nature of disturbance } & \multirow[t]{2}{*}{$\begin{array}{c}\text { Average } \\
\text { depth (m) }\end{array}$} & \multirow[t]{2}{*}{$\begin{array}{c}\text { Substratum } \\
(\%)\end{array}$} & \multirow[t]{2}{*}{$\begin{array}{c}\text { Canopy } \\
(\%)\end{array}$} \\
\hline & $\mathrm{X}$ & $\mathrm{Y}$ & & & & \\
\hline K1 & 436,617 & 579,119 & Fishing, dishes, laundry & 2.34 & & 0 \\
\hline $\mathrm{K} 2$ & 435,800 & 579,202 & Agricultural waste & 2.17 & Mud (95\%) Sand (5\%) & 0 \\
\hline \multirow[t]{2}{*}{ K3 } & 435,017 & 579,456 & $\begin{array}{l}\text { Laundry, dishes, } \\
\text { agricultural waste }\end{array}$ & 2.64 & & 0 \\
\hline & & & & & Sand $(35 \%)$ & \\
\hline \multirow[t]{2}{*}{ K4 } & 429,117 & 580,611 & $\begin{array}{l}\text { Agricultural waste, } \\
\text { fishing, deforestation }\end{array}$ & 1.75 & Plant debris (40\%) & 70 \\
\hline & & & & & Mud (25\%) & \\
\hline
\end{tabular}


sampled at the sites during the eight sampling campaigns with a kick-net $(25 \times$ $20 \mathrm{~cm}, 500 \mu \mathrm{m}$ mesh size). At each site 5 net strokes are sampled. A net stroke consists of pulling the net over a distance approximately $1 \mathrm{~m}$. The initial net is followed by two round trips on the surface to capture the dislodged organisms. The samples were then pooled to make one composite sample per site. Samples were fixed on $70 \%$ ethanol and stored in labelled polyethylene flasks.

In the laboratory, specimens were sorted and identified to the lowest possible taxonomic level using a stereomicroscope Olympus SZ (40× magnification) and a series of identification keys [24]-[29]. FFGs of aquatic insects were identified based on Cummins et al. (2005) [10] and Tachet et al. (2010) [29]. Temperature, $\mathrm{pH}$, conductivity and dissolved oxygen were measured in situ at each sampling site with a portable multi-parameter (HANNA), water transparency was determined with a Secchi disc. Water was also collected with bottle of $1 \mathrm{~L}$ at each sampling site for nutrients (phosphorus and nitrate) analysis in the laboratory using Rodier et al. (2009) [30] methods.

\subsection{Data Analysis}

Species diversity was calculated using the Shannon-Weaver diversity index and Pielou evenness. Taxonomic richness was rarefied in each site per sampling period. Precisely, rarefied richness was used to avoid any bias related to differences in abundances between samples [31]. Before performing comparison analyses, data normality was checked using Shapiro test. As the biotic and environment data distribution follow non-normal distribution $(\mathrm{P}<0.05)$, the non-parametric test of Kruskal-Wallis was performed to compare data variability between sampling sites. When Kruskal-Wallis test is significant, Mann-Whitney test was used for pairwise comparison. The significance threshold was $p=0.05$. Analyses were conducted using the R package. The occurrence percentage (FO) was calculated using the following formula: $\mathrm{FO}=(\mathrm{Ni} / \mathrm{Nts}) \times 100$; with $\mathrm{Ni}=$ number of samples containing a given species $\mathrm{i}$, and $\mathrm{Nts}=$ total number of samples collected. The FO was used to classify species following (Dajoz, 2000) [32]: FO > 50: very frequent species; $25<\mathrm{FO} \leq 50$ : frequent species; $\mathrm{FO} \leq 25$ : rare species.

The FFGs include the calculation of the relative abundance of each FFG, Top-down predator control (ratio of predators to all other FFGs) and the calculation of the balance between autotrophy and heterotrophy (production $[\mathrm{P}] /$ respiration $[\mathrm{R}]$ ). This index was calculated as the ratio of scrapers to (shredders + total collectors):

$$
\mathrm{P} / \mathrm{R}=\frac{\mathrm{scr}}{\mathrm{shr}+\mathrm{fc}+\mathrm{gc}}
$$

scr, shr, fc and gc represent the abundances of scrapers, shredders, filterers-collectors and gatherers-collectors respectively. According to Cummins et al. (2005) [10], $\mathrm{P} / \mathrm{R}>0.75$ indicates autotrophy.

Focused Principal Component Analysis (FPCA) [33] was used to assess relationships between taxa abundance and environmental variables. Focused Prin- 
cipal Component Analysis (FPCA) is a variation of the traditional principal component analysis. It uses the same types of matrix as the PCA but differs from it in that it is centred or focused on a variable xi. Indeed, it allows a graphical representation of the correlations that exist between this variable xi and the other variables. The graph provides access not only to the nature (positive or negative) but also to the significance $(\mathrm{P}<0.05)$ of the correlations between variable xi and the other variables. It is also possible to observe on the graph the correlations between the other variables.

In this study, the FPCA was used to determine the variables that influence the abundance of macroinvertebrate taxa that contribute at least $5 \%$ of the total abundance. This analysis was performed using the psy package on the $\mathrm{R}$ software.

\section{Results}

\subsection{Environment Variables}

Table 2 shows the variations of environmental variables measured in the four studied sites.

Temperature ranged from $25.9^{\circ} \mathrm{C}(\mathrm{K} 1)$ to $32^{\circ} \mathrm{C}(\mathrm{K} 2)$. Conductivity varied between $14 \mu \mathrm{S} / \mathrm{cm}$ and $37.1 \mu \mathrm{S} / \mathrm{cm}$ (K1). The dissolved oxygen variation was situated between $0.1 \mathrm{mg} / \mathrm{L}$ and $11.3 \mathrm{mg} / \mathrm{L}(\mathrm{K} 1)$. The water transparency of sites values varied from $10 \mathrm{~cm}$ to $218 \mathrm{~cm}$ (K1). Concerning the $\mathrm{pH}$, it varied from 5.19 $(\mathrm{K} 1)$ to $8.01(\mathrm{~K} 4)$. Regarding the phosphate and nitrate, their values were low, varied from $0.015 \mathrm{mg} / \mathrm{L}(\mathrm{K} 2)$ to $0.31 \mathrm{mg} / \mathrm{L}(\mathrm{K} 3)$ and from $0.1 \mathrm{mg} / \mathrm{L}$ (K2 and $\mathrm{K} 4$ ) to $2.65 \mathrm{mg} / \mathrm{L}$ (K2 and K3) respectively. Analysis showed no significant differences of these parameters between sites (Kruskal-Wallis, $\mathrm{P}>0.05$ ).

\subsection{Composition and Distribution of Aquatic Insects}

A total of 5562 aquatic insect individuals from six orders, 32 families and 68 taxa have been recorded. The order Coleoptera was the most diversified with 19 taxa and eight families. The order of the Diptera was as follows with 15 taxa and

Table 2. Median, minimum and maximum values of environmental variables measured at the four sampling sites of Kodjoboué lake (South-East, Côte d'Ivoire).

\begin{tabular}{ccccc}
\hline Parameters & K1 & K2 & K3 & K4 \\
\hline Temperature $\left({ }^{\circ} \mathrm{C}\right)$ & $28.19(25.9-31.9)$ & $29.2(27-32)$ & $29.1(27.2-31.6)$ & $29.2(27.2-31.3)$ \\
Conductivity $(\mu \mathrm{S} / \mathrm{cm})$ & $29.3(14-37.1)$ & $22.5(19-36)$ & $21.94(20-28.1)$ & $22.6(21-27.2)$ \\
$\begin{array}{c}\text { Dissolved oxygen } \\
(\mathrm{mg} / \mathrm{L})\end{array}$ & $1.50(0.1-11.3)$ & $6.4(0.17-9.5)$ & $6.31(0.15-9.36)$ & $6.26(0.14-8.11)$ \\
$\begin{array}{c}\text { Transparency }(\mathrm{cm}) \\
\text { pH }\end{array}$ & $113(10-218)$ & $99.5(50-125)$ & $110(51-190)$ & $98(73-124)$ \\
& $6.4(5.19-7.5)$ & $6.48(6-7.69)$ & $6.63(5.3-7.66)$ & $6.50(6-8.01)$ \\
Phosphate $(\mathrm{mg} / \mathrm{L})$ & $0.078(0.039-0.13)$ & $0.07(0.015-0.22)$ & $0.059(0.016-0.31)$ & $0.08(0.017-0.18)$ \\
Nitrate $(\mathrm{mg} / \mathrm{L})$ & $1.22(0.2-2.21)$ & $0.83(0.1-2.65)$ & $0.64(0.2-2.65)$ & $0.70(0.1-1.77)$ \\
\hline
\end{tabular}


seven families. The least diversified order was the order of Trichoptera with 03 taxa and two families. Families of Dytiscidae and Chironomidae dominated abundances with respectively $33.5 \%$ and $26 \%$. The K1 site of Lake Kodjoboué recorded the highest number of aquatic insects (77.68\%) followed by the site K2 with $10.48 \%$ of the insects harvested. The lowest number of insects was recorded in K4 (5.44\%) (Table 4).

\subsection{Frequency of Occurrence}

Table 3 shows the percentages of the very common, frequent and rare taxa at the four sites. The percentages of very frequent taxa vary between $06.25 \%$ (K4) to $12.96 \%(\mathrm{~K} 1)$. Those of frequent taxa varied between $21.87 \%$ (K4) to $38.88 \%$ (K1 and K3). Regarding rare taxa, they are the most numerous at all sites with percentages ranging from $48.14 \%$ (K1) to $71.87 \%$ (K4). Polypedilum deletum (Diptera) was common to the four sites with a very high occurrence $(\mathrm{FO} \geq 50)$.

The qualitative data on sampling at the lake sites considered are summarized in Table 5. Site K1, with 54 taxa, has the highest taxonomic richness. It is followed by the site K3 with 36 taxa. Site K2, with 32 taxa, has the lowest taxonomic richness of all the stations considered. Of the taxa identified, only 13 are common to all four sites.

The different sites are compared with each other based on their taxonomic composition (Table 5). Sites K1 and K4 contain more common taxa (26), site pairs (K1 - K3) and (K1 - K3) contain fewer common taxa with 18 taxa each. It should also be noted that site K3 contains more specific taxa (04), while sites K1, $\mathrm{K} 2$ and $\mathrm{K} 4$ each contain only one specific taxon (Figure 2).

\subsection{Diversity Metrics}

The lowest values of the three diversity metrics, Shannon-Weaver index, Pielou's Evenness Index and rarefied richness were recorded at site K4. However, the highest values were observed at the site $\mathrm{K} 3$ for these three metrics. Of these three metrics, only rarefied richness does not show significant variation between the different sites ( $\mathrm{P}>0.05$; Mann-Whitney) (Figure 3).

\subsection{Functional Feeding Groups}

Five major FFGs were identified in this study: predators (pre), scrapers (scr), shredders (shr), gatherers-collectors (gc), and filter-collectors (fc). The analysis

Table 3. Proportions of aquatic insects very frequent, frequent and rare at the different sampling sites of the Kodjoboué lake (South-East of Côte d'Ivoire).

\begin{tabular}{cccc}
\hline Sites & Very frequent (\%) & Frequent (\%) & Rare (\%) \\
\hline K1 & 12.96 & 38.88 & 48.14 \\
K2 & 06.45 & 35.48 & 58.06 \\
K3 & 08.33 & 38.88 & 52.77 \\
K4 & 06.25 & 21.87 & 71.87 \\
\hline
\end{tabular}


Table 4. List of the aquatic insects' taxa found in the four sites of Kodjoboue with their functional groups and their relative contribution (South-East, Côte d'Ivoire).

\begin{tabular}{|c|c|c|c|c|c|c|c|c|}
\hline \multirow{2}{*}{ Orders } & \multirow{2}{*}{ Famillies } & \multirow{2}{*}{ Taxa } & \multicolumn{4}{|c|}{ Sampling sites } & \multirow{2}{*}{$\begin{array}{l}\text { Feeding } \\
\text { groups }\end{array}$} & \multirow{2}{*}{$\begin{array}{c}\text { Relative } \\
\text { contribution (\%) }\end{array}$} \\
\hline & & & $\mathrm{K} 1$ & $\mathrm{~K} 2$ & $\mathrm{~K} 3$ & $\mathrm{~K} 4$ & & \\
\hline \multirow[t]{7}{*}{ Ephéméroptera } & Baetidae & Baetis sp. & $* *$ & $* *$ & * & * & gc & 0.90 \\
\hline & & Cloeon sp..$^{(\mathrm{MA})}$ & $* * *$ & $* *$ & * & $* *$ & gc & 6.15 \\
\hline & & Procleon sp. & * & & & & gc & 0.05 \\
\hline & Caenidae & Caenis sp. & & ** & & & $\mathrm{gc}$ & 0.04 \\
\hline & Ephemeridae & Eatonica sp. & & & * & & pre & 0.02 \\
\hline & Polymitarcydae & Povilla adusta & & $* *$ & & * & $\mathrm{gc}$ & 0.09 \\
\hline & Tricorythidae & Tricorythys sp. & * & & & & - & 0.07 \\
\hline \multirow[t]{11}{*}{ Odonata } & Coenagrionidae & Ceriagrion sp. & $* *$ & * & * & * & pre & 0.52 \\
\hline & & Pseudagrion sp. & * & * & $* * *$ & $* * *$ & pre & 2.28 \\
\hline & Libellulibidae & Bradinopygas sp. & $* *$ & * & & & pre & 0.43 \\
\hline & & Chalcostephia sp. & * & & & & pre & 0.38 \\
\hline & & Crocothemis sp. & $* *$ & & $* *$ & * & pre & 0.61 \\
\hline & & Libellula sp. & & * & & & pre & 0.04 \\
\hline & & Macrodiplax sp. & ** & * & $* *$ & * & pre & 1.49 \\
\hline & & Pantala flavescens & * & & * & * & pre & 0.38 \\
\hline & & Trithemis dorsalis & $* *$ & & * & * & pre & 0.25 \\
\hline & & Urothemis sp. & & & * & & pre & 0.20 \\
\hline & & Zygonyx torrida & $* *$ & & & & pre & 0.09 \\
\hline \multirow[t]{13}{*}{ Heteroptera } & Belostomatidae & Diplonychus sp. & $* * *$ & $* * *$ & $* * *$ & $* *$ & pre & 2.28 \\
\hline & Gerridae & Eurymetra sp. & $* *$ & * & $* *$ & $* *$ & pre & 0.22 \\
\hline & & Limnogonus sp. & ** & & & & pre & 0.04 \\
\hline & & Rhagadotarsus sp. & ** & & & * & pre & 0.16 \\
\hline & Hydrometridae & Hydrometra sp. & & & * & & pre & 0.02 \\
\hline & Naucoridae & Laccocoris sp. & ** & & * & * & pre & 0.58 \\
\hline & & Naucoris sp. & * & $* *$ & $* *$ & * & pre & 1.19 \\
\hline & Nepidae & Ranatra linearis & & $* *$ & & * & pre & 0.07 \\
\hline & Notonectidae & Anisops sp. & & & * & & pre & 0.04 \\
\hline & & Notonecta sp. & & * & * & & pre & 0.09 \\
\hline & Pleidae & Plea sp. & * & & * & & pre & 0.05 \\
\hline & Veliidae & Microvelia sp. & & * & $* *$ & $* *$ & pre & 3.94 \\
\hline & & Rhagovelia sp. & * & * & & * & pre & 0.52 \\
\hline \multirow[t]{3}{*}{ Trichoptera } & Ecnomidae & Ecnomus sp. & & * & $* *$ & * & $\mathrm{fc}$ & 0.11 \\
\hline & Hydropsychidae & Polymorphanisus sp. & & * & & $* *$ & $\mathrm{fc}$ & 0.09 \\
\hline & & Cheumatopsyche sp. & & & & * & $\mathrm{fc}$ & 0.02 \\
\hline
\end{tabular}


I. A. Camara et al.

\section{Continued}

\begin{tabular}{|c|c|c|c|c|c|c|c|c|}
\hline \multirow[t]{19}{*}{ Coleoptera } & Curculionidae & Pseudobagous longulus & $* * *$ & $* *$ & $* *$ & * & $\operatorname{shr}$ & 1.76 \\
\hline & & Notaris sp. & * & & & & $\operatorname{shr}$ & 0.04 \\
\hline & Dytiscidae & Agabus sp. & $* *$ & & & & pre & 0.04 \\
\hline & & Bidessus sp. & $* *$ & & & & pre & 0.16 \\
\hline & & Hydaticus sp. & * & $* *$ & $* *$ & * & pre & 0.31 \\
\hline & & Hydrovatus sp. ${ }^{(\mathrm{MA})}$ & $* * *$ & $* *$ & $* *$ & * & pre & 31.07 \\
\hline & & Hyphydrus & * & & * & * & pre & 1.74 \\
\hline & & Laccophilus sp. & * & * & & * & pre & 0.18 \\
\hline & Elmidae & Esolus sp. ${ }^{(\mathrm{MA})}$ & * & & & & gc & 5.00 \\
\hline & & Limnius sp. & $* *$ & * & * & * & $\mathrm{gc}$ & 3.99 \\
\hline & & Potamodytes sp. & $* *$ & & & & scr & 0.18 \\
\hline & Gyrinidae & Dineutus sp. & * & & * & & pre & 0.04 \\
\hline & & Orectogyrus sp. & * & * & & & pre & 1.37 \\
\hline & Haliplidae & Haliplus sp. & * & & & & $\operatorname{shr}$ & 0.59 \\
\hline & Hydrochidae & Hydrochus sp. & * & & & & $\mathrm{scr}$ & 0.05 \\
\hline & Hydrophilidae & Amphiops sp. & * & & $* *$ & & pre & 2.41 \\
\hline & & Enochrus sp. & $* * *$ & & $* *$ & * & pre & 0.63 \\
\hline & & Hydrobius sp. & * & & $* *$ & & pre & 0.18 \\
\hline & Noreridae & Noterus sp. & * & & & & pre & 0.04 \\
\hline \multirow[t]{15}{*}{ Diptera } & Chaoboridae & Mochlonyx sp. & * & & & & pre & 0.04 \\
\hline & Ceratopogonidae & Culicoides sp. & * & * & * & & fc & 0.02 \\
\hline & Chironomidae & Ablabesmyia sp. & ** & * & & $* *$ & $\mathrm{gc}$ & 1.02 \\
\hline & & Chironomus sp. & $* * *$ & & * & & gc & 3.58 \\
\hline & & Cricotopus sp. & $* *$ & & & & gc & 1.24 \\
\hline & & Cryptochironomus sp. & $* *$ & $* *$ & & $* *$ & $\mathrm{gc}$ & 1.53 \\
\hline & & Polypedilum abyssiniae & & * & * & & $\mathrm{gc}$ & 0.47 \\
\hline & & Polypedilum deletum ${ }^{(M A)}$ & $* * *$ & $* * *$ & $* * *$ & $* * *$ & $\mathrm{gc}$ & 18.07 \\
\hline & & Stenochironomus sp. & * & & & & $\mathrm{gc}$ & 0.02 \\
\hline & & Clinotanypus sp. & * & & * & * & gc & 0.18 \\
\hline & & Stictochironomus sp. & $* *$ & * & & & $\mathrm{gc}$ & 0.23 \\
\hline & Culicidae & Culex sp. & $* *$ & & $* *$ & & $\mathrm{fc}$ & 0.68 \\
\hline & Dixidae & Dixa sp. & ** & $* *$ & $* *$ & * & $\mathrm{gc}$ & 0.43 \\
\hline & Rhagionidae & & * & & & & - & 0.02 \\
\hline & Syphiridae & & * & & & & $\mathrm{gc}$ & 0.02 \\
\hline \multicolumn{2}{|c|}{ Taxonomic richness } & 68 & 54 & 31 & 36 & 32 & & \\
\hline
\end{tabular}

${ }^{* * *}$ Very frequent $(\% \mathrm{OF}>50) ;{ }^{* *}$ frequent $(25<\% \mathrm{OF} \leq 50) ;{ }^{*}$ rare $(\% \mathrm{OF} \leq 25) .(\mathrm{MA})=$ taxa representing at least $5 \%$ of the total abundance. 
Table 5. Synthesis of qualitative sampling data from sampling sites in Lake Kodjoboué.

\begin{tabular}{ccccc}
\hline \multirow{2}{*}{ Diversity measures } & \multicolumn{5}{c}{ Sampling sites } \\
\cline { 2 - 5 } & K1 & K2 & K3 & K4 \\
\hline Number of taxa & 54 & 31 & 36 & 32 \\
Families & 25 & 19 & 20 & 18 \\
Orders & 6 & 6 & 6 & 6 \\
Common taxa & & \multicolumn{2}{c}{13} & \\
\hline
\end{tabular}

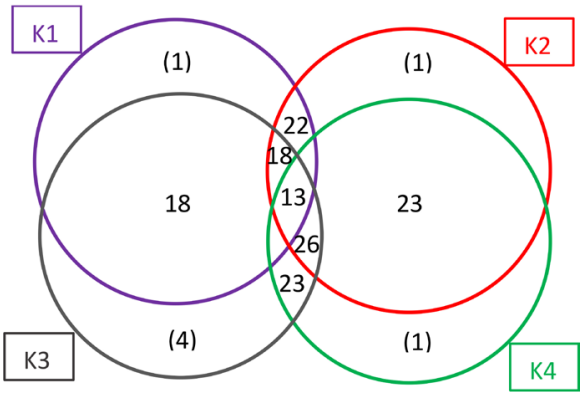

Figure 2. Schematic representation of the number of taxa shared by all sites pairwise in the Kodjoboué lake and in the different sites of the lake: the number of taxa specific to the same site in brackets.

(A)

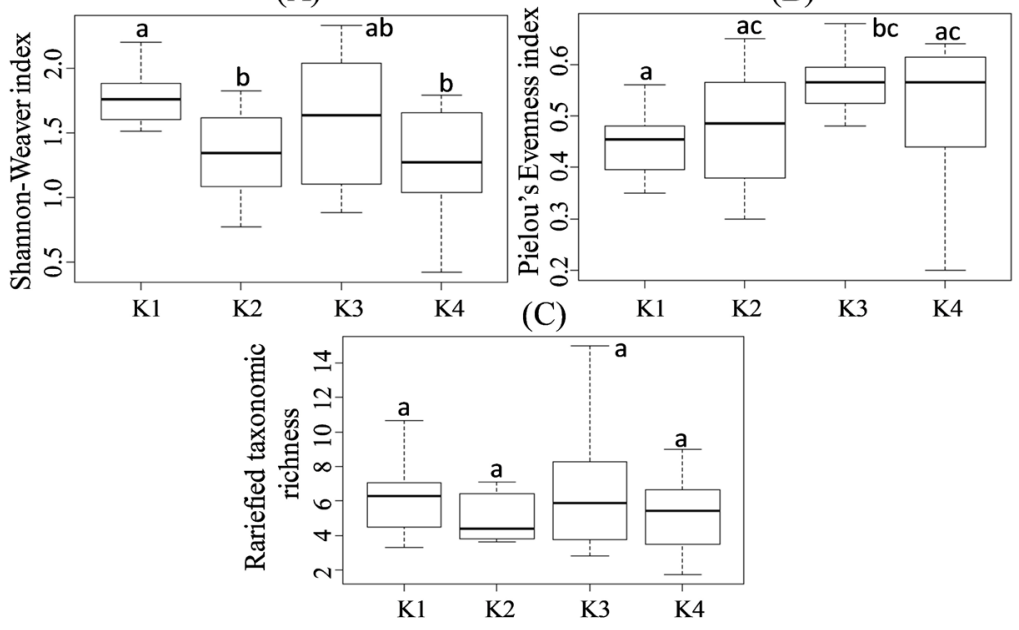

Figure 3. Box-plots showing variation of Shannon-Weaver index (A), Pielou's Evenness index (B) and Rarefied taxonomic richness (C) of Kodjoboué lake (K1 - K4). Different letters $(\mathrm{a}, \mathrm{b}$ and $\mathrm{b})$ on box-plots denote significant differences between them (Mann-Whitney, $\mathrm{P}<0.05)$.

of the functional composition of the assemblage revealed that the predators were the most abundant (Figure 4) with a proportion of $53.74 \%$ of the insects harvested. Gatherers-collectors ranked second with $42.05 \%$ of the total insect population. A proportion of $2.84 \%$ was observed for the shredders, while filter-collectors and scrapers had the lowest proportions respectively $0.91 \%$ and $0.44 \%$ of the total abundance. 
At the spatial scales (study sites), the sites $\mathrm{K} 2$ and $\mathrm{K} 3 \mathrm{had}$ a high proportion of predators compared to the collector-gatherers, while the $\mathrm{K} 1$ and $\mathrm{K} 4$ sites recorded more gatherers (Figure 5). No scraper was recorded in sites K2, K3 and K4 during this study.

The value of the autotrophic heterotrophy index is less than 0.75 at all four sites. For the top-down predator control, the values are all greater than 0.2 on all our sites (Table 6).

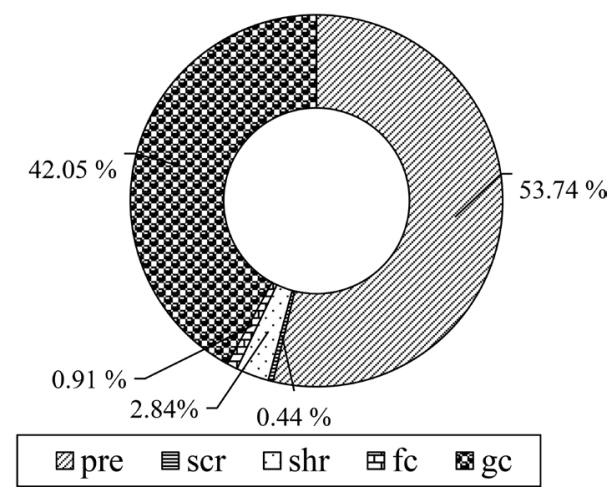

Figure 4. Overall percentage representation of the five Functional Feeding Groups (FFGs) recorded in Kodjoboué lake.

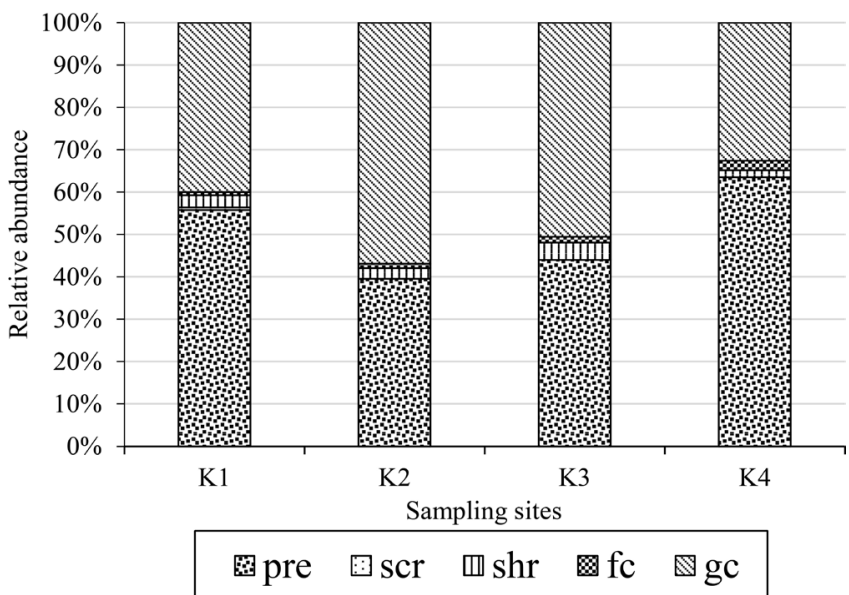

Figure 5. Percentages of aquatic insects Functional Feeding Groups (FFGs) sampled from the study sites.

Table 6. Ratios of aquatic insects Functional Feeding Groups in Kodjoboué lake. Ratios are based on numerical abundance of Functional Feeding Groups (FFGs). The autotrophy to heterotrophy (production $[\mathrm{P}] /$ respiration $[\mathrm{R}]$ ) index was calculated as the ratio of scrapers to (shredders + total collectors). Top-down predator control is the ratio of predators to all other FFGs.

\begin{tabular}{ccc}
\hline Sites & P/R & Top-down predator control \\
\hline K1 & 0.01 & 1.26 \\
K2 & 0 & 0.65 \\
K3 & 0 & 0.78 \\
K4 & 0 & 1.74 \\
\hline
\end{tabular}




\subsection{Correlation between Aquatic Insects and Environment Variables}

Focused Principal Component Analysis (FPCA) was performed using environmental parameters with a focus on the most abundant taxa (at least $5 \%$ of total abundance). Thus, the FPCA states that Hydrovatus sp.is significantly and negatively influenced $(\mathrm{P}<0.05)$ by dissolved oxygen $\left(\mathrm{O}_{2}\right)$. Also, this insect is positively correlated with parameters such as conductivity (CND), nitrate $\left(\mathrm{NO}_{3}\right)$, temperature $(\mathrm{T})$ and transparency (Transp) but negatively correlated with $\mathrm{pH}$ and phosphate $\left(\mathrm{PO}_{4}\right)$. Polypedilum deletum is significantly and positively correlated with nitrate $(\mathrm{P}<0.05)$. This taxon is negatively correlated with temperature, $\mathrm{pH}$ and dissolved oxygen but positively correlated with other parameters. Cloeon sp. is significantly correlated with dissolved oxygen and $\mathrm{pH}(\mathrm{P}<0.05)$. This Ephemeroptera is positively correlated with transparency, but negatively correlated with other parameters. As for Esolus sp., it is negatively correlated with $\mathrm{pH}$ and temperature but positively correlated with conductivity, nitrate, phosphate and transparency. Esolus sp. is significantly correlated with dissolved oxygen $(\mathrm{P}<0.05)$ (Figure 6$)$.

\section{Discussion}

In this study, the water temperature range of Kodjoboue Lake was between $25.9^{\circ} \mathrm{C}$ and $31.9^{\circ} \mathrm{C}$ and was considered relatively warm. This trend reflects the temperature in the tropics. This range is close to that observed in Taabo Lake by Kouamé et al. (2010) [17]. Our low conductivity levels (14 to $37.1 \mu \mathrm{S} / \mathrm{cm}$ ) would indicate low levels of natural or anthropogenic sediments throughout Kodjoboué Lake. With regard to dissolved oxygen, the range is between 0.10 and $11.3 \mathrm{mg} / \mathrm{l}$. This range is greater than that obtained at Taabo Lake $(3.62-9.2 \mathrm{mg} / \mathrm{l})$ by Kouamé et al., (2010) [17]. The amplitude of temperature and dissolved oxygen variations can be linked to the lack of coverage plant on the lake. The transparency of the water varies between 10 and $218 \mathrm{~cm}$ at Lake Kodjoboué. This range is higher than that observed (73 and $112 \mathrm{~cm}$ ) at Ayamé Lake by Diétoa (2002) [16]. Low levels of nitrate $(0.1-2.65 \mathrm{mg} / \mathrm{l})$ and phosphorus $(0.015-0.31 \mathrm{mg} / \mathrm{l})$ were recorded. Nitrate levels are higher than those obtained in Lake Taabo (0.05 -1.95 $\mathrm{mg} / \mathrm{l}$ ) and those in phosphate are low compared to those obtained in the same lake $(0.24-28.47 \mu \mathrm{mol} / \mathrm{l})$ by Kouamé et al. (2010) [17]. These environmental variables do not vary significantly from one site to another. However, there are wide variations in conductivity, dissolved oxygen and transparency within the sites. This is due to the fact that the samples were taken at different seasons. Indeed, during our study we sampled both in the dry season and in the rainy seasons.

Out of a total of 5562 aquatic insects composed of 6 orders, 32 families and 68 taxa, Coleoptera are the most diversified and the most abundant with a high proportion for Dytiscidae. The preponderance of Coleoptera is explained by the fact that they are the only holometabolous insects to appear in both the imaginal and larval forms in aquatic environments. They colonize various habitats when 

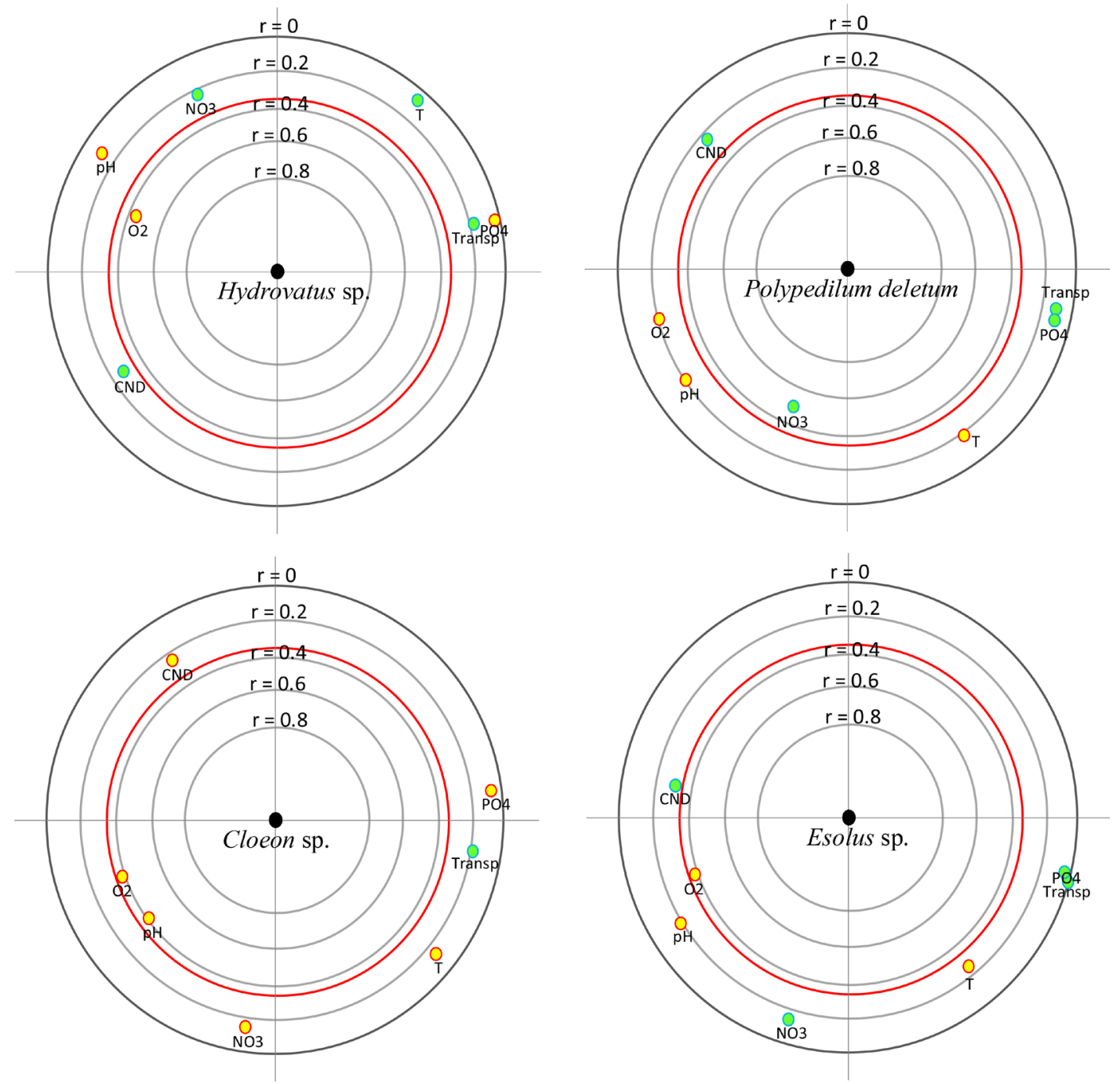

Figure 6. Graphs showing the results of the Focused Principal Component Analysis (FPCA) based on the abundance of taxa with at least $5 \%$ of the total abundance as a dependent variable and environmental variables as independent variables. Yellow dots correspond to items negatively correlated to taxa abundance; green dots indicate items positively correlated to taxa abundance. The dots inside the red circle represent items significantly correlated $(\mathrm{P}<0.05)$ with taxa abundance. The uncorrelated points form right angles to the center of the circle. $\mathrm{T}=$ temperature; $\mathrm{CND}=$ conductivity; $\mathrm{pH}=$ hydrogen potential; Transp = transparency; $\mathrm{O}_{2}=$ dissolved oxygen; $\mathrm{NO}_{3}=$ nitrate; $\mathrm{PO}_{4}=$ phosphate.

conditions become hostile to reduced interspecific competition in other species [34].

In this study, the lowest values of the three metrics of diversity calculated the Shannon-Weaver index (1.74), the Pielou's Evenness index (0.16) and the rarefied richness (1.74) have been recorded in K4. However, the highest values were observed in K3, 2.33 for the Shannon-Weaver index, 0.68 for the Pielou's Evenness index and 15.31 for the rarefied richness. The site $\mathrm{K} 3$ would therefore be the most diversified and the most stable and $\mathrm{K} 4$ the least diversified. The low diversity of the site $\mathrm{K} 4$ is undoubtedly linked to the numerous agricultural activities that are carried out there. Indeed, the shores of this site have several rubber 
plantations whose maintenance requires fertilizers and pesticides. Of these three metrics, only the rarefied wealth deemed to be unbiased does not show a significant difference between the sites. These sites would therefore be subject to the same environmental conditions.

Chironomidae, Polypedilum deletum is the only taxon that was most common at all sites. The regular harvest of these chironomids would be linked to their broad spectrum of resilience and morphological, physiological and behavioural adaptations.

Five functional feeding groups were identified in this study: predators (pre), scrapers (scr), shredders (shr), gatherers-collectors (gc) and filter-collectors (fc). Among the different functional feeding groups, the percentage of predators was higher than that of the other groups in our sites, followed by gatherers-collectors. Predator preponderance would probably be related to prey availability, especially gatherer-collectors such as Chironomidae ranked second in abundance. In fact, predatory organisms reproduce proportionally to the availability of food. The growth rate of predators is therefore an increasing function of prey [35].

Shredders, filter-collectors and scrapers had the lowest proportions of total abundance. The low proportion of shredders in this lake is thought to be related to the fact that in tropical areas high temperatures increase the decomposition of litter and leaves by microbial activity [36]. They do not have enough plant debris to be shredded, hence their low proportion. Several studies have shown the low proportion of shredders in the tropics [37] [38] [39] [40] [41]. The waters of Lake Kodjoboué would be disturbed because according to Babour et al. (1996) [42], specialized feeders, such as shredders and scrapers, are presumed to be more sensitive to disturbance. Their low proportions are due to a disturbed environment.

The $\mathrm{P} / \mathrm{R}$ ratio $(<0.75$ at all sites) indicates that our four sites are characterized as heterotrophic. The K1 site is the least heterotrophic compared to the other three sites. According to Savić et al. (2017) [43], this would mean that the dominant staple food chain for aquatic insect communities has been found to be non-native detritus. Concerning the Top-down predator control, all values are above 0.2 at all our sites. According to Masese et al. (2014) [44], the value of the predator-prey ratio must be between 0.1 and 0.2 for there to be a balance between predators and prey. In other words, none of our sites have predator-prey balance or top-down control. So, we have an overabundance of predators in Lake Kodjoboué.

Correlations between the most abundant taxa and environmental parameters using the Focused Principal Component Analysis (FPCA) show a strong negative correlation between Hydrovatus sp. (Predator) and dissolved oxygen. This correlation reveals the ability of this Beetle to live in anoxia. Unlike the Ephemeroptera Cloeon sp. is positively correlated with dissolved oxygen. Indeed, Ephemeroptera are known to live in highly oxygenated environments [45]. Polypedilum deletum (gatherers-collectors) is significantly and positively corre- 
lated showing the polluting resistance of the Chironomidae family.

\section{Conclusion}

This work enabled us to identify 68 aquatic insect taxa divided into six orders and 32 families. Beetles were the most abundant in both quality and quantity. Site K4, subject to intense agricultural activity, had the least diversified and least balanced stand with the lowest values of the Shannon-Weaver index, the Pielou Evenness index and rarefied richness. Functionally, five major FFGs were identified in this study: predators (pre), scrapers (scr), shredders (shr), gatherers-collectors $(\mathrm{gc})$ and filter-collectors ( $\mathrm{fc})$. Among the different functional feeding groups, the percentage of predators was higher than that of other groups at our sites. The $\mathrm{P} / \mathrm{R}$ ratio indicated that our four sites, are characterized as heterotrophic with $\mathrm{K} 1$ as the least heterotrophic. Top-down predator control ratio revealed an overabundance of predators. The diversity and Functional Feeding Groups metrics of aquatic insects used to describe the state of Kodjoboue lake reveal a disturbed state, therefore of poor quality. It would be important to implement a sustainable management program for this lake in order to conserve its biodiversity.

\section{Acknowledgements}

This work was supported by the PASRES (Strategic Support Program Scientific Research) (Côte d'Ivoire), under research project number 110 entitled "Approche écosystémique de la pêche comme moyen d'exploitation durable des ressources halieutiques dans la zone humide de Grand-Bassam" (ecosystem approach to fisheries as a means of sustainable exploitation of fisheries resources in the Grand-Bassam wetland).

\section{Conflicts of Interest}

The authors declare no conflicts of interest regarding the publication of this paper.

\section{References}

[1] Camargo, J.A., Alonso, A. and De la Puente, M. (2004) Multimetric Assessment of Nutrient Enrichment in Impounded Rivers Based on Benthic Macroinvertebrates. Environmental Monitoring and Publishers, 96, 233-249. https://doi.org/10.1023/B:EMAS.0000031730.78630.75

[2] Woodcock, T.S. and Huryn, A.D. (2007) The Response of Macroinvertebrates Production to a Pollution Gradient in a Headwater Stream. Freshwater Biology, 52, 177-196. https://doi.org/10.1111/j.1365-2427.2006.01676.x

[3] Arimoro, F.O. and Ikomi, R.B. (2009) Ecological Integrity of Upper Warri River, Niger Delta Using Aquatic Insects as Bioindicators. Ecological Indicators, 9, 455-461. https://doi.org/10.1016/j.ecolind.2008.06.006

[4] Santhosh, S.K. and Ashadevi, R. (2017) Biomonitoring as a Strategy for Ecosystem Health-A Case Study at the Upper Reaches of Vamanapuram River, Kerala. Inter- 
national Journal of Science and Research, 6, 750-754.

[5] El Husseiny, I.M., Mona, M.H., Seif, A.I. and Yassin, M.T. (2015) Aquatic Insects as Bio Indicators for Pollution in Some Egyptian Streams. Sci-Afric Journal of Scientific Issues, Research and Essays, 3, 607-615.

[6] Gagnon, E. and Pedneau, J. (2006) Surveillance Volontaire (SurVol) Benthos, guide du volontaire, programme de surveillance volontaire des petits cours d'eau. CVRB, Québec, 25 p.

[7] Dolédec, S., Statzner, B. and Bournard, M. (1999) Species Traits for Future Biomonitoring across Ecoregions Patterns along a Human-Impacted River. Freshwater Biology, 42, 7737-758. https://doi.org/10.1046/j.1365-2427.1999.00509.x

[8] Bady, P., Dolédec, S., Fesl, C., Gayraud, S., Bacchi, M. and Scholl, F. (2005) Use of Invertebrate Traits for the Biomonitoring of European Large Rivers: The Effects of Sampling Effort on Genus Richness and Functional Diversity. Freshwater Biology, 50, 159-173. https://doi.org/10.1111/j.1365-2427.2004.01287.x

[9] Archaimbault, V., Rosebery, T.J. and Morin, S. (2010) Traits biologiques et écologiques, intérêt et perspectives pour la bio-indication des pollutions toxiques. Sciences et Territoires, 1, 46-51. https://doi.org/10.3917/set.001.0046

[10] Cummins, K.W., Merritt, R.W. and Andrade, P.C. (2005) The Use of Invertebrate Functional Groups to Characterize Ecosystem Attributes in Selected Streams and Rivers in South Brazil. Studies on Neotropical Fauna and Environment, 40, 69-89. https://doi.org/10.1080/01650520400025720

[11] Usseglio-Polatera, P., Bournaud, M., Richoux, P. and Tachet, H. (2000) Biological and Ecological Traits of Benthic Freshwater Macroinvertebrates: Relationships and Definition of Groups with Similar Traits. Freshwater Biology, 43, 175-205. https://doi.org/10.1046/j.1365-2427.2000.00535.x

[12] Tomanova, S., Moya, N. and Oberdorff, T. (2008) Using Macroinvertebrate Biological Traits for Assessing Biotic Integrity of Neotropical Streams. River Research and Applications, 24, 1230-1239. https://doi.org/10.1002/rra.1148

[13] Diaz, A.M., Alonso, M.L.S. and Gutiérrez, M.R.V.A. (2007) Biological Traits of Stream Macroinvertebrates from a Semi-Arid Catchment: Patterns along Complex Environmental Gradients. Freshwater Biology, 53, 1-21. https://doi.org/10.1111/j.1365-2427.2007.01854.x

[14] Rawer-Jost, C., Böhmer, J., Blank, J. and Rahmann, H. (2000) Macroinvertebrate Functional Feeding Group Methods in Ecological Assessment. Hydrobiologia, 422-423, 225-232. https://doi.org/10.1023/A:1017078401734

[15] Sankaré, Y. (1991) Etude comparative de la macrofaune associée aux racines de Pistia stratiotes L. (Araceae) du lac de barrage d'Ayamé II et du fleuve Comoé (Côte d'Ivoire). Journal Ivoirien d' Océanologie et Limnologie, 1, 131-138.

[16] Diétoa, Y.M. (2002) Entomofaune et stratégies alimentaires des poissons du genre Brycinus (Characidae) en milieux fluviales et lacustre (Bassin Bia et Agnéby; Côte d'Ivoire). Thèse de Doctorat, Université d'Abob-Adjamé, Côte d'Ivoire, 261.

[17] Kouamé, M.K., Diétoa, M.Y., Da Costa, S.K., Edia, O.E., Ouattarra, A. and Gourène G. (2010) Aquatic Macroinvertebrate Assemblages Associated with Root Masses of Water Hyacinths, Eichhornia crassipes (Mart.) Solms-Laubach, 1883 (Commelinales: Pontederiaceae) in Taabo Lake, Ivory Coast. Journal of Natural History, 44, 257-278. https://doi.org/10.1080/00222930903457208

[18] Kouamé, M.K., Diétoa, M.Y., Edia, O.E., Da Costa, S.K., Ouattara, A. and Gourène G. (2011) Macroinvertebrate Communities Associated with Macrophyte Habitats in 
a Tropical Man-Made Lake (Lake Taabo, Côte d'Ivoire). Knowledge and Management of Aquatic Ecosystems, 20, 1-12.

https://doi.org/10.1051/kmae/2010035

[19] Diomandé, D., Kpai, N.N., Kouadio, K.N., Da Costa, K.S. and Gourène, G. (2013) Spatial Distribution and Structure of Benthic Macroinvertebrates in Artificial Reservoir: Taabo Lake (Côte d'Ivoire). International Journal of Biological and Chemical Sciences, 7, 1503-1514. https://doi.org/10.4314/ijbcs.v7i4.7

[20] Kra, K.M., Camara, A.I., Edia, O.E., Konan, K.M., Ouattara, A. and Diomandé, D. (2018) First Survey of Aquatic Macroinvertebrates Diversity in Kodjoboué Lake (South-East of Côte d'Ivoire). International Journal of Fisheries and Aquatic Research, 3, 23-30.

[21] Principe, R., Gualdoni, C., Oberto, A., Raffaini, G. and Corigliano, M. (2010) Spatial Temporal Patterns of Functional Feeding Groups in Mountain Streams of Córdoba, Argentina. Ecología Austral, 20, 257-268.

[22] Halle, B. and Bruzon, V. (2006) Profil environnemental de la Côte d'Ivoire. Rapport final de la Commission Européenne, 133 p.

[23] Brou, Y. (1997) Analyse et dynamique de la pluviométrie en milieu forestier ivoirien. Thèse de Doctorat 3ème cycle, Université de Cocody Abidjan, Côte d'Ivoire, $200 \mathrm{p}$.

[24] Déjoux, C., Elouard, J.M., Forge, P. and Malsin, J. (1981) Catalogue iconographique des insectes aquatiques de Côte d'Ivoire. Rapport ORSTOM. Bouaké, Côte d'Ivoire, $172 \mathrm{p}$.

[25] Day, J.A., Stewart, B.A. and de Moor, I.J. (2003) Guide to the Freshwater Invertebrates of Southern Africa. Volume 9: Diptera. Rapport N TT 201/02 Water Research Commission, South Africa, 200 p.

[26] De Moor, I.J., Day, J.A. and Moor, F.C. (2003) Guide to the Freshwater Invertebrates of Southern Africa. Volume 7: Insecta I: Ephemeroptera, Odonata and Plecoptera. Rapport N ${ }^{\circ}$ TT 207/03 Water Research Commission, South Africa, 288 p.

[27] De Moor, I.J., Day, J.A. and Moor, F.C. (2003) Guide to the Freshwater Invertebrates of Southern Africa. Volume 8: Insecta II: Hemiptera, Megaloptera, Neuroptera, Trichoptera and Lepidoptera. Rapport $N^{\circ}$ TT 214/03 Water Research Commission, South Africa, 209 p.

[28] Stals, R. and De Moor, I.J. (2007) Guides to the Freshwater Invertebrates of Southern Africa. Volume 10: Coleoptera. Rapport N TT 320/07 Water Research Commission, South Africa, 263 p.

[29] Tachet, H., Richoux, P., Bournaud, M. and Usseglio-Polatera, P. (2010) Freshwater Invertebrates: Taxonomy, Biology, Ecology. CNRS Editions, Paris.

[30] Rodier, J., Legube, B. and Merlet, N. (2009) L'Analyse de l'Eau. 9è édition, Dunod, Paris, $1579 \mathrm{p}$.

[31] Grall, J. and Coïc, N. (2005) Synthèse des méthodes d'évaluation de la qualité du benthos en milieu côtier. Rebent, 48, 90.

[32] Dajoz, R. (200) Précis d’Ecologie. 7ème édition, Dunod, Paris, 615 p.

[33] Falissard, B. (1999) Focused Principal Component Analysis: Looking at a Correlation Matrix with a Particular Interest in a Given Variable. Journal of Computational and Graphical Statistics, 8, 906-912. https://doi.org/10.1080/10618600.1999.10474855

[34] Ben moussa, A., Chahlaoui, A., Rour, E. and Chahboune, M. (2014) Taxonomic Diversity and Structure of Benthic Macrofauna of Surface Water of Khoumane River. 
Moulay Idriss Zerhoun, Morocco. Journal of Materials and Environmental Science, 5, 183-198.

[35] Arditi, R. and Ginzburg, L.R. (1989) Coupling in Predator-Prey Dynamics: Ratio-Dependence. Journal of Theoretical Biology, 139, 311-326. https://doi.org/10.1016/S0022-5193(89)80211-5

[36] Barman, B. and Gupta, S. (2015) Spatial Distribution and Functional Feeding Groups of Aquatic Insects in a Stream of Chakrashila Wildlife Sanctuary, Assam, India. Knowledge and Management of Aquatic Ecosystems, 416, 37. https://doi.org/10.1051/kmae/2015028

[37] Gonçalves, J.R., França, J.S., Medeiros, A.O., Rosa, C.A. and Callisto, M. (2006) Leaf Breakdown in a Tropical Stream. International Review of Hydrobiology, 91, 164-177. https://doi.org/10.1002/iroh.200510826

[38] Li, A.O. and Dudgeon, D. (2009) Shredders: Species Richness, Abundance, and Role in Litter Breakdown in Tropical Hong Kong Streams. Journal of the North American Benthological Society, 28, 167-180. https://doi.org/10.1899/08-043.1

[39] Masese, F.O., Raburu, P.O. and Muchiri, M. (2009) A Preliminary Benthic Macroinvertebrate Index of Biotic Integrity (B-IBI) for Monitoring the Moiben River, Lake Victoria Basin, Kenya. African Journal of Aquatic Science, 34, 1-14. https://doi.org/10.2989/AJAS.2009.34.1.1.726

[40] Kaboré, I., Moog, O., Alp, M., Guenda, W., Koblinger, T., Mano, K., Ouéda, A., Ouédraogo, R., Trauner, D. and Melcher, A.H. (2016) Using Macroinvertebrates for Ecosystem Health Assessment in Semi-Arid Streams of Burkina Faso. Hydrobiologia, 766, 57-74. https://doi.org/10.1007/s10750-015-2443-6

[41] Madomguia, D., Zebaze, T.S.H. and Fomena, A. (2016) Macro Invertebrates Functional Feeding Groups, Hilsenhoff Biotic Index, Percentage of Tolerant Taxa and Intolerant Taxa as Major Indices of Biological Assessment in Ephemeral Stream in Sudano-Sahelian Zone (Far-North, Cameroon). International Journal of Current Microbiology and Applied Sciences, 5, 792-806. https://doi.org/10.20546/ijcmas.2016.510.086

[42] Barbour, M.T., Gerritsen, J., Griffith, G.E., Frydenborg, R., McCarron, E., White, J.S. and Bastian, M.L. (1996) A Framework for Biological Criteria for Florida Streams Using Benthic Macroinvertebrates. Journal of the North American Benthological Society, 15, 185-211. https://doi.org/10.2307/1467948

[43] Savić, A., Đorđević, M., Jušković, M. and Pešić, V. (2017) Ecological Analysis of Macroinvertebrate Communities Based on Functional Feeding Groups: A Case Study in Southeastern Serbia. Biologica Nyssana, 8, 159-166.

[44] Masese, F.O., Kitaka, N., Kipkemboi, J., Gettel, G.M., Irvine, K. and McClain, M.E. (2014) Macroinvertebrate Functional Feeding Groups in Kenyan Highland Streams: Evidence for a Diverse Shredder Guild. Freshwater Science, 33, 435-450. https://doi.org/10.1086/675681

[45] Arimoro, O.F., Ikomi, B.R. and Iwegbue, A.M. (2007) Water Quality Changes in Relation to Diptera Community Patterns and Diversity Measured at an Organic Effluent Impacted Stream in the Niger Delta, Nigeria. Ecological Indicators, 7, 541-552. https://doi.org/10.1016/j.ecolind.2006.06.002 